"I feel that if it were possible for those far-seeing men who founded this Institution to come amongst us to-day, they would consider that the great heritage which they left us has been fully preserved."

\section{Training of Mercantile Marine Officers}

Some important recommendations for the better training of apprentices for sea service are contained in a report just issued by an Advisory Committeo to the Manning Committee of the Shipping Federation. To qualify for the position of a junior officer in the British Mercantile Marine, it is necessary to serve an apprenticeship of four years, or three years if a boy has passed through the Conway, or Worcester, or Pangbourne College, and to pass the Board of Trade examination for second mate. At present, there is no recognised course of instruction or any uniformity in training for apprentices or cadets, and very often it is only with the greatest difficulty that apprentices prepare themselves for examination. Some shipping companies have special schemes of training; but such is not the general case. It is now proposed that a Central Board of Control should be set up with the power to draw up a standard syllabus of instruction, to set annual examination papers, to give practical advice to captains of ships in matters of education, to appoint local boards of examiners and to publish periodical statistics relating to the scheme of education. The Advisory Committee expresses its belief that, if shipowners adopt the scheme and give it their practical support, it will secure the sympathy and assistance of both the Board of Trade and the Board of Education. Apprentices at sea suffer from many disabilities as compared with their fellows ashore, and some recognised course of training such as is proposed has long been overdue. It is to be hoped, therefore, that the recommendations put forward will receive the support they deserve.

\section{Research in the Automobile Industry}

AT the annual dinner of the Institution of Automobile Engineers on October 12, Sir Herbert Austin referred to the debt the automobile industry owes to the Department of Scientific and Industrial Research; and the extent to which the industry receives help from the Department is dealt with in the recent annual report of the Research and Standardization Committee of the Institution. During the year ending June 30, 1934, the total income of the committee was $£ 9,963$, which included $£ 5,000$ from the Society of Motor Manufacturers and Traders, $£ 1,962$ from subscriptions and $£ 2,500$ from the Department. The year's expenditure on research was about $\mathfrak{£ 6 , 0 0 0}$. To stimulate further research, the Department has offered to increase its contribution to $£ 5,000$ if the industry will find $£ 10,000$, and to $\mathfrak{1 0 , 0 0 0}$ if the industry will find $£ 15,000$. As the output of motor-cars in Great Britain was stated by Sir Frank Smith at the dinner to be 285,000 a year, it should not be difficult for the industry to find a sum which amounts to practically a shilling a car. Researches are already in hand on cylinder wear, valve seat wear, bearings, oil consumption, piston temperatures, brakes and other matters, and from these valuable information has been obtained.

\section{Battery-Electric Cars}

AFTER many years of almost suspended animation, the battery-electric vehicle industry is showing signs of life. At the Exide motor show, Mr. D. P. Dunne stated that the monthly output of these vehicles in Great Britain is larger than it has ever been before. Compared with petrol vehicles, they make less noise and produce less atmospheric pollution. Statistics prove that their life is much longer and their maintenance is much less than that of any other form of mechanically propelled road vehicle. Several corporations are using electric vans in connexion with their electrical apparatus hiring schemes. The West Ham undertaking has vans with a speed of 20 miles per hour and a range of 50 miles per charge. They use an electric motor coupled to the back-axle through differential gearing. The charging arrangements are quite simple : a 'jack' is provided on the dashboard for connecting with the mains and there is an automatic control to limit the rate of charging. This undertaking has introduced a night tariff of $0.66 \mathrm{~d}$. per unit for vehicle charging. In certain cases, such vehicles will prove more economical than petrol vans.

\section{Investigation of Cosmic Rays by Sounding Balloons}

Accordrng to a recent article distributed by Science Service, Washington, D.C., Dr. Arthur H. Compton, of the University of Chicago, proposes to use small sounding balloons that will automatically send wireless signals recording pressure and tempera. ture of the air and the intensity of the cosmic rays. The idea is not new, having been developed for example by Prof. J. M. Benade, of Lahore, and by Prof. Moltchanoff, of Leningrad (Nature, Dec. 31, 1932 , p. 1006). The risks attending direct exploration of the stratosphere are obvious, and these special balloons are designed to avoid them, while greatly reducing expense; they are said not to exceed $15 \mathrm{ft}$. in diameter at release, and to weigh only $16 \mathrm{lb}$. Radio signals are to be emitted from a single valve oscillator. The movements of a special barometer will affect the wave-length of the signals, and the signals will be interrupted by a balance wheel, of which the rate of oscillation will be controlled by temperature. They will also be interrupted at each discharge of a cosmic ray counter-an instrument which discharges at a rate dependent upon the conductivity of the atmosphere, which in turn is affected by the cosmic raysthe length of time between such breaks giving an indication of cosmic ray intensity just as the lengths of the intervals between interruptions previously mentioned will indicate the temperature. It is understood that Dr. Compton's measurements will not entirely replace those made with manned 'stratosphere balloons', but will supplement them and allow some information to be obtained from sparsely populated regions where neither manned balloons nor balloons that release self-recording instruments when they burst can be employed, in the first case 